\title{
Towards the fulfilment of three generations of rights: A theological contribution by Koos Vorster
}

\begin{abstract}
Author:
Nico N. Koopman ${ }^{1}$

Affiliation:

${ }^{1}$ Faculty of Theology,

Stellenbosch University,

South Africa

Correspondence to:

Nico Koopman

Email:

nkoopman@sun.ac.za

Postal Address:

Faculty of Theology Theology,

Stellenbosch University, 171

Dorp Street, Stellenbosch

7600 , South Africa

Dates:

Received: 22 Mar. 2011

Accepted: 20 June 2011

Published: 25 Oct. 2012

How to cite this article: Koopman, N.N., 2012,

'Towards the fulfilment of

three generations of rights:

A theological contribution by

Koos Vorster', In die Skriflig/

In Luce Verbi 46(1), Art.

$\# 45,6$ pages. http://dx.doi.

org/10.4102/ids.v46i1.45
\end{abstract}

C 2012. The Authors.

Licensee: AOSIS

OpenJournals. This work

is licensed under the

Creative Commons

Attribution License.
In this article the theological contribution of Koos Vorster to human rights discourses was discussed. It was shown how he focused upon all three generations rights, namely the first generation civil and political rights, second generation social, economic and cultural rights, and third generation developmental and ecological rights. He appreciates the importance of nurturing citizens and leaders of public and civic virtue and character for the implementation of rights and the creation of a human rights culture. He also gives special attention to the implementation of ecological rights and therefore discussed various forms of ecocide. Ultimately, Vorster stimulates systematic theological discourses on ecological rights by viewing the implementation of ecological rights as a theological matter. It had to do with the heart of Christian faith.

Aangaande die vervulling van drie generasies van regte: 'n Teologiese bydrae deur Koos Vorster. In hierdie artikel was die teologiese bydrae van Koos Vorster tot menseregte-diskoerse bespreek. Dit dui aan dat hy op al drie generasies van menseregte gefokus het, naamlik eerste generasie burgerlike en politieke regte, tweede generasie sosiale, ekonomiese en kulturele regte en derde generasie ontwikkelings- en ekologiese regte. Hy waardeer die belangrikheid van die vorming van burgers en leiers van burgerlike en openbare deug en karakter vir die implementering van regte en die bou van 'n menseregtekultuur. Hy het spesiale aandag gegee aan die implementering van ekologiese regte en hy het derhalwe die verskillende vorme van die vernietiging van die natuurlike omgewing bespreek. Hy stimuleer sistematies-teologiese denke oor ekologiese regte. Hy het die implementering van ekologiese beskou as 'n teologiese saak. Dit het met die hart van die Christelike geloof te make gehad.

\section{Introduction}

The vision of a human rights culture has been cherished for a very long time by millions of South Africans. In the Freedom Charter (South African Congress Alliance 1955), this vision reflects important features such as non-racialism, hospitality, socio-economic liberation, security and comfort for all. At the launch of the anti-apartheid movement, the United Democratic Front, the vision of a South African society based on human rights was formulated as follows: we want one united, undivided, non-racial, non-classist, non-sexist democratic South Africa where peace and justice reign supreme. Eventually South Africans from a diversity of backgrounds as well as different religious and secular orientations adopted the consensus on the human rights foundations of our society as is articulated in the Bill of Rights of the South African Constitution (Republic of South Africa 1996). Central elements of this human rights foundation are equality, freedom, justice, equity and, especially, human dignity.

Although the Bill of Rights is not an infallible document, we might state without hesitation that the vision of a human rights society is articulated very clearly in this document. Our paperwork has been completed successfully. In order to look good not only on paper, but also on the playing field, we now need to work hard at establishing a human rights culture. This task entails keeping alive the vision of a society based on human rights; that institutions be established and law and policymaking processes and practices, such as theory-building, influencing of public opinion and the development of an ethics of responsibility - all of which require a lot of wisdom and discernment - be embarked upon. This will ensure that all rights that is the so-called political, socio-economic, and developmental and ecological rights be enforced, implemented and fulfilled; and that citizens be equipped to fulfil their public responsibility to cherish and embody this human rights vision and to participate with wisdom in the processes that serve the implementation of these rights.

A human rights culture in South Africa, Germany and elsewhere in the world, therefore, firstly entails the adherence to the vision of a society built on the values of dignity, equality, freedom, 
justice and equity. Secondly, it refers to the institutions, measures, processes, discourses and practices that are established to ensure the implementation and embodiment of the vision of a human rights society. Thirdly, a human rights culture has in mind the development of citizens of public virtue and character in all walks of life, who participate in keeping this human rights vision alive and in embodying it.

In his theological labour, Koos Vorster ${ }^{1}$ presents concrete suggestions for the fulfilment of three generations of human rights. He namely argues that policies be made and implemented to enhance the fulfilment of rights and he proposes that the formation of people of virtue and character enjoy priority in this process. He specifically emphasises the implementation of so-called third generation developmental and ecological rights.

\section{On the fulfilment of three generations of rights}

Human rights scholar, Allan Gewirth (1984), offers a useful distinction on the various conditions relating to human rights:

A right is fulfilled when the correlative duty is carried out, i.e. when the required action is performed or the prohibited action is not performed. A right is infringed when the correlative duty is not carried out, i.e. when the required action is not performed or the prohibited action is performed. Thus someone's right to life is infringed when the prohibited action of killing him is performed, someone's right to medical care is infringed when the required action of providing him with medical care is not performed. A right is violated when it is unjustifiably infringed, when the required action is unjustifiably not performed or the prohibited action is unjustifiably performed. And a right is overridden when it is justifiably infringed, so that there is sufficient justification for not carrying out the correlative duty, and the required action is justifiably not performed or the prohibited action is justifiably performed. (p. 92)

Vorster (2004:119-120) argues that despite the fulfilment of rights, situations may arise where rights cannot be fulfilled. In some instances rights should be limited. According to Vorster, this happens because rights, like many moral directives, are not absolute. He also argues that especially the so-called second generation social, economic and cultural rights might be limited when a state does not have the economic capacity to fulfil these rights. The limitation of rights should, however, not be the result of the mismanagement of resources by the state, or the abuse of state power. It should be used as a last resort. Moreover, whenever there is doubt about the limitation of rights, the fulfilment - and not the limitation option - should enjoy priority. In a country such as South Africa, with its wealth of resources, limitation of rights will, in my opinion, not easily be justifiable.

However, Vorster (2004) is committed to the fulfilment of human rights. This is reflected in his research on human

1.In Vorster's (2004) book on human rights, entitled Ethical perspectives on human rights, the accumulation of his many years of thinking on this subject is brought together and systematised. This article, therefore, borrows mainly from this work. rights and in his involvement in various local and global institutions that seek the fulfilment of rights. Besides his teaching and research in the field of human rights, he is also engaged in international initiatives that aim to implement human rights on a global level. As such, Vorster (2004) focuses on all three generations of rights and discusses the historical development of the three generations. Besides the first generation political and civil rights, he also calls for attention to the second generation social, economic and cultural rights. He describes them as follows:

Economic and social rights are part of the second-generation human rights that emerged in the latter part of the twentieth century. These rights are collectivist in nature over and against the individualist approach of the first generation rights. All of these rights are very important for the purpose of alleviating poverty and in the development of society - especially in the developing world. (p. 119)

\section{On human rights and 'right humans'?}

The theological labour of Koos Vorster consistently pleads for the nurturing of citizens of public virtue and character who embody the human rights vision. He, therefore, argues that in order to implement and fulfil human rights we need 'right humans', thereby concurring with the plea of a growing number of social and political theorists, as well as various theologians, in arguing that civic virtue be restored for the sake of building democratic societies that serve the common good of all its inhabitants.

William Galston (1991:221-224) has compiled a very influential list of four categories of civic virtues that enable democracies to flourish, namely general virtues (courage, law-abidingness and loyalty), social virtues (independence and open-mindedness), economic virtues (work ethic, capacity to delay self-gratification, adaptability to economic and technological change) and political virtues (capacity to discern and respect the rights of others, willingness to demand only what can be paid for, ability to evaluate the performance of those in office, willingness to engage in public discourse). In his influential study on the role of civil society in Italy, Robert Putnam (1993) argues that the success of regional governments was related to the civic virtue, or social capital, of citizens and, amongst others, their ability to trust, to participate in public life and their sense of justice. Although they had the same institutions, the various post-war regional governments achieved different levels of success. Putnam contributes these differences not to the different income and education levels of citizens, but to differences in civic virtue and social capital. ${ }^{2}$

From Vorster's (2004:96-98) book on human rights, one can infer that the Ten Commandments play a crucial role in the nurturing of citizens of virtue and character, who enhance the fulfilment of human rights through their personal choices and their participation in policymaking processes, as well as through their personal and public actions and practices.

2.For a collection of essays that deal theologically with the appeal that democracies need citizens who embody civic virtue, human excellence, common decency, public responsibility and civic engagement, see T.W. Boxx and G.M. Quinlivan (eds.) (2000). 


\section{On the fulfilment of ecological rights}

\section{Towards an ecological theology}

It is strongly appreciated that Vorster focuses explicitly on the implementation of ecological rights. This is a theme that does not enjoy prominence in South African and international theological discourses on human rights. In this section, Vorster's (2004) description of ecocide is discussed. It is argued that he prompts further thinking on a theological response to ecocide; consequently, building-blocks for the development for such a theological response are discussed and attention in this regard is specifically given to the thoughts of two Dutch systematic theologians, namely Abraham van de Beek and Hendrikus Berkhof.

\section{The faces of ecocide}

In line with the work of Broswimmer, Vorster (2004:246-247) identifies three major stages in the development of ecocide, the first of which occurred 60000 years ago during the huntergatherer stage of human subsistence. Homo sapiens employed extra somatic energy in the form of fire to extend the use and eventual exploitation of nature for hunting and dietary purposes. In the same phase, language developed and thus enabled human beings to develop sophisticated forms of culture and common life. These group activities and increase of knowledge through linguistic means enabled humans to exploit nature to a higher extent. Ecocide constitutes the destructive side of human cultural development.

The second stage occurred with the transition from a huntergatherer to an agricultural society. An agricultural mode of existence implies demographic and geographic expansion, both of which lead to ecological disasters such as land damage caused by poor irrigation methods and deforestation (Vorster 2004:247-248).

During the third phase, namely modernity, ecocide developed from a localised and regional phenomenon to become a global problem. Specifically, four factors played a role in this development, namely the increasing division of labour, the capitalist mode of production, the emergence of the modern nation-state and the accompanying process of colonisation. Modernity is now characterised by processes of political, economic and cultural globalisation. Vorster (2004:248) describes the negative dimension of globalisation as globalism. Globalism intensifies ecological destruction. The magnitude of transnational companies, the income of which often exceeds the gross domestic product of many nations, makes it difficult for national governments to contain them and ensure that they adhere to environmentally friendly policies. Thus, in the context of their quest for profits, these companies tend to cause immense ecological destruction. Globalism also leads to an intensification of poverty by creating more poor people in the world who unavoidably have to exploit natural resources in order just to survive. As such, in the context of globalism, fundamentalist, nationalist and paramilitarist groups flourish and have increasing access to nuclear, chemical and biological weaponry that, in itself, constitutes a major threat to the environment.

Although Vorster does not completely concur with the views of thinkers such as Lyn White and Jimmy Loader about the role the Christian doctrine of creation has played over centuries in the destruction of the natural environment, he does agree that traditional Christian thinking on God, humans and creation has, indeed, led to deistic views about God's involvement in the world, and also to dualisms between the human and natural dimensions of God's one creation. Deism flourished especially during the 18th century and taught that God has left the world behind like a wind-up clock. Humans can now explore it without God intervening again. Besides the wonderful scientific discoveries that human exploration of nature brought to the fore, the doors were also opened for the exploitation of nature through this theological belief that God has left everything in the hands of humans and that he will not intervene again in history and nature. The dualism which interpreted human dominion over the earth in oppressive, rather than steward and servant, terms also fed the ecocide practiced by humans.

Thus, Vorster (2004) provides a theological diagnosis of the ecological destruction in which we are engaged as human beings. He challenges us to develop faithful ecological theologies that will eventually serve the quest to fulfil ecological rights.

\section{Creation is good, but was never paradise}

The perspectives on creation of Reformed theologian, Bram van de Beek, from the Netherlands, provide buildingblocks for such an ecological theology. His perspectives are especially helpful because they focus on the brokenness of creation.

Van de Beek (1996:178) argues that it is not possible to talk about creation other than Christologically. Creation is, from the beginning, the creation of Jesus Christ who dies on the cross. Creation is indeed good, but there never was a creation of paradise living. There is no such thing as 'paradise lost'. Eden is not paradise, but a garden where man discovers that it is not good to be alone. Eden is not a paradise with idyllic pictures of perfect harmony between humans and animals. Humans give names to animals, that is, they give them etiquettes and subject them. Eden is not a place of carefree love between man and woman, but their togetherness soon develops into a drama of anxiety and guilt, with a curse as outcome.

According to Van de Beek (1996:179, 182), creation is to be understood in terms of the cross of Christ; creation came into being for Christ and for the cross. Creation under the cross reflects the image of the suffering Servant and thus has no form or majesty or desirable appearance. From creation under the cross we hide our faces. The most impressive expression of creation is not the beautiful spring mornings of the Dutch woods or the friendly jackal that crosses my path in those bushes, but the blood and tears of the suffering in 
this world. In line with Noordmans, Van de Beek (1996:180) states that we should not describe and understand creation in terms of our image, but rather in terms of the image of God, which is no other image than that of the cross which unmasks every illusion of paradise-living and a golden creation. The redemption of creation goes through the cross, as symbolised by baptism. Only through the union with Christ, through being implanted into him, through the inoculation of our nature into his, through the sanctification of our unholiness, can we be saved.

Van de Beek (1996:181) concurs with Noordman's warning that we should not only focus on the incarnation of Christ, and use that as an argument to recognise only the beauty and worth of creation. He argues that the beauty of nature should also be acknowledged. But the incarnation should be interpreted together with the cross, as well as with the longing of the Spirit for the renewal of creation. Pneumatology helps us to know that God dwells in this world as his home, but the eschatological longing of the Spirit teaches us that home has not been fully actualised yet; down here it is not yet.

The theme of the renewal of all of creation is also emphasised by Van de Beek (1996:210-211), who appreciates Langdon Gilkey's nuanced portrayal of the relationship between eschatological renewal and historical brokenness. Gilkey foresees a new future where the redemptive possibilities which we started will be fulfilled by the divine logos. The divine love reunites us with God and with one another. This redeemed future is not a mere continuation of the present broken history, but redemptive processes and possibilities that we started in history will be fulfilled. And, for Van de Beek, it is crucial that the suffering narratives of millions of people and of the rest of creation be taken up in that fulfilment and reunification.

Van de Beek (1996:206-209) refers to C.H. von Weizsäcker, who introduced the notion that the quest for justice and peace should be linked to the theme of the wholeness and integrity of creation. The World Council of Churches built on this thinking through its Canberra assembly with the conference theme of 'come Holy Spirit, renew the whole creation', and with its famous programme, 'justice, peace and the integrity of creation'. Since Canberra, the idea that the whole of creation participates in, and is included, in the coming of God's kingdom, is an indispensable part of ecumenical thinking. Van de Beek (1996:207) cites Van Ruler and Berkhof, two prominent Dutch systematic theologians who had earlier also emphasised the idea that the renewal of the world is not anthropomonistic, but that the so-called nonhuman part of creation is included in this work of renewal and perfection of the Spirit.

Van de Beek (1996:328) also appeals to Calvin, who, according to him, employs the baptism of children to show God's concern for animals. Baptism affirms that God enters into covenant with children who cannot explicitly and consciously express faith in him. In the same manner he enters into covenant with animals who also cannot consciously express their faith. Amidst his opposition to anthropocentrism and amidst his plea for the inclusion of the nonhuman part of creation in the renewal work of the Spirit, Van de Beek (1996:330-331) still pleads for a special place for human beings, and for the study of anthropology as a specific dogmatic locus. His main argument resides in the fact that Christ became human, and not animal. Christ is vere deus et vere human, and not vere deus et vere equus [horse], or vere dues et vere falco [hawk].

The Christological and pneumatological look at creation helps us to view creation in terms of its brokenness, vulnerability and suffering. It frees us from a misplaced nostalgic longing for a lost paradise, or for misplaced human efforts to restore that lost good and perfect past. This perspective helps us to know that the brokenness that we experience, as well as the tragic expressions of ecocide, is part of broken reality. The recognition of this brokenness from the beginning of creation does not, however, lead to cynicism, apathy and withdrawal. Rather, it feeds our eschatological longing and collaboration with the Spirit for the renewal and redemption of all of creation.

\section{The renewal of social and natural structures}

Van de Beek's predecessor at Leiden University in the Netherlands, Hendrikus Berkhof, is more explicit about the renewal of the broken creation. Berkhof $(1979: 520,522)$ argues that the renewal of the world, that is, of all the structures - social and natural - in which humans live is not only a matter of ethics, but of dogmatics. It is not only through the responsible actions of humans that the world is renewed, but through the work of the triune God. He specifically describes the renewal of the social and natural world as the work of the Holy Spirit; although, the Spirit renews humans personally. We should, therefore, understand renewal in personal terms, but not in personalistic terms. The Spirit does not do incomplete work. The Spirit renews humans and the social and natural world, the social and natural structures in which we live.

Human beings and these social and natural structures are two sides of the same coin: if God renews humans he also renews these structures. Berkhof (1979:521) finds ample scriptural evidence for this comprehensive renewal, including, (1) in the laws of the Pentateuch and the theocratic social order built on them, (2) in the appeals and judgement of the prophets on national and international matters, (3) in the words and deeds through which Jesus opposes contemporary powers and intercedes on behalf of the poor, (4) in the thinking of Paul about the lordship of Christ over all the powers of the world and (5) in Paul's directives in his letters on social relationships between Jews and Greeks, strong and weak, rich and poor, citizens and leaders, lord and slave, husband and wife, parents and children. On the basis of Paul's proclamation in Romans 8 about the waiting, hoping and sighing of creation for renewal, and on the basis of his appeals in Colossians 1 to the cosmic work of Christ, one can add the renewal of the relationship between humans and nature to this list.

Berkhof (1979:521) reckons that various interrelated factors caused the Church to pay inadequate attention to the social and natural dimensions of renewal. Amongst these factors are the influence of creation orders, respect for the government 
and the static structures they invent, less attention to social and natural structures in the New Testament in comparison to the Old Testament, and the personal and inner impressions of the work of the Spirit. Berkhof (1979:521) also warns that the Church tends to neglect crucial aspects of our faith, and that we often only give fresh attention to those neglected aspects when things go wrong in the world with regard to that matter. For instance, it took the Church more than 150 years to learn the lesson of the French Revolution. God often has to teach the church through the world, rather than the other way around.

The Spirit sanctifies the social and natural structures of the world through the actions of sanctified human beings, as well as through the direct critical intervention of the Spirit (Berkhof 1979:529-530). For Berkhof, sanctification refers to the manner in which the holy love of God motivates and guides the thinking and actions of humans. Structures are holy in the sense that they can either hinder or advance the sanctification of human actions. Economic structures, with their strong motives of profits and competition, hinder the holy attempts of a businessman who wants to do justice to his employees. Laws and policies which compel us to contribute to community actions on behalf of the poor and disabled enhance the holy actions of humans. Holy structures give space to the intentions of the holy love of God.

Structural sanctification has expressed itself in Western cultures in features such as individualising, humanisation, socialising, and a more formal and future-oriented perspective. These features led to scientific and technological developments in Western societies and to the establishment of so-called welfare-states, with their ethos of communal care for the most vulnerable in society. This renewal of structures, according to Berkhof (1979:533), is not to be found directly in Scripture, but it is a legitimate and impressive application of the biblical witness. Berkhof (1979:532, 536-537) argues that the mentioned features of renewal in Western societies are not the result of secularisation, but of the proclamation of the Christian gospel which places high value on these features of life. The proclamation of these values might, and indeed did, pave the way for secularisation. This is also the reason why some church leaders originally opposed these developments.

Berkhof (1979:536) also points out how the cherished notion of freedom and emancipation has, besides its positive manifestations in modern Western societies, also led to negative manifestations, amongst others ecocide. This autonomy makes no room for God, responsiveness to his calling, repentance and redemption. This autonomy feeds individual and collective egoism and consumerism, a cruel domination and subjugation of creation by humans instead of caring for creation, and eventually meaningless existence and consequent vulnerability to the destructive salvationpromising powers of our day.

Berkhof (1979:540-541) introduces the need for an intervention that constitutes a discontinuity with the experience of limited renewal in the world, and the experience of a power that opposes the redemptive and renewing power of the Spirit. He argues that two leaps are required for the total renewal of the world. The first leap refers to the resurrection of Christ. In the resurrection, God affirms and justifies his Son because of the work that he has done in the Father's name. The second leap refers to God's affirmation of the work of the Spirit. Through this leap God frees the power that his Spirit works in the world. This leap, this affirmation, this setting free of the power of the Spirit, constitutes a discontinuity which, in the end, serves the continuity which normal processes cannot serve adequately.

The judgement of God, according to Berkhof (1979:541), plays, as in the renewal of humans, an indispensable role in the renewal of all of creation. In the judgement (literally crisis, separation) the final separation and purification takes place. We can only speak about this process in symbols in order not to remain silent. Judgement occurs in connection with the past, and it simultaneously opens perspectives on God's future. In the final judgement, creation is redirected and made right so that all that is alien to love disappears and all that is left is God's holy love which infiltrates all relationships. Then God becomes all in everyone (persons), and all in all (all structures). All the loveless and egoists are rejected, and all the helpless people and the downtrodden are elevated. Through this judgement, the world raises up renewed as an earth on which justice dwells.

We now live between the two leaps, en route to the second leap of the affirmation of the Spirit, the freeing of the power that the Spirit brings forth in the world, and the fulfilment of the work of the Spirit - we participate in the work of the triune God. Both believers and those who function with a secular autonomous orientation that makes no room for Christ, provide building-blocks for the sanctification of the structures. Our most faithful contribution to the complete renewal is to make choices in line with the final judgement, choices that cause the ripening of that which will, in the end, prove to be corn and not chaff (Berkhof 1979:541).

Although Berkhof does not focus explicitly enough on the renewal and sanctification of structures in an ecological context, he provides building-blocks for such an attempt. He offers a strong theological rationale for the comprehensive nature of the work of redemption, renewal and sanctification of the triune God. He teaches us to take note of what is going on around us, namely environmental decay, but, more so, to take note of the central aspects of our faith relating to this decay that we neglect. And perhaps we neglect for very long those themes in Christian faith that have in mind the integrity and wholeness of creation without which justice and peace discourse cannot be dealt with adequately, especially not in a world where ecocide reigns supreme. Berkhof's challenge to develop systematic theological reflection, that is, reflection from the heart of Christian doctrine, from the perspective of the actions, promises and faithfulness of God in the world, deserves serious attention. ${ }^{3}$

\section{Conclusion}

The theological labour of Koos Vorster indeed attempts to be public. It aims to contribute to the transformation of public life. His focus upon human rights is a well-executed

3.In South Africa, Ernst Conradie's (cf. 2000, 2005, amongst others) reflects on ecological challenges from systematic theological perspective are noteworthy. His work deserves serious and urgent attention. 
effort to engage in contemporary human rights discourses from a theological perspective. His theological parameters coincide very well with those offered by theologians such as Van de Beek and Berkhof. He focuses upon all generations of rights and appreciates the importance of the formation of citizens and leaders of public and civic virtue for creating a human rights culture. He calls for attention to a theological focus upon the implementation of ecological rights, and he stimulates discourses about the formation of ecological theologies. Ecocide needs to be dealt with as a theological matter, as an issue that has to do with the heart of Christian faith. His public theology serves South African churches, the academy and broader society well.

\section{Acknowledgements \\ Competing interests}

The author declares that he has no financial or personal relationships which may have inappropriately influenced him in writing this article.

\section{References}

Berkhof, H., 1979, Christelijk Geloof, Een inleiding tot de geloofsleer, 4th edn., G.F. Callenbach B.V., Nijkerk.

Boxx, T.W. \& Quinlivan, G.M. (eds.), 2000, Public morality, civic virtue, and the problem of modern liberalism, Eerdmans, Grand Rapids.

Conradie, E.M., 2000, Hope for the earth, Vistas on a new century, University of the Western Cape, Bellville.

Conradie, E.M., 2005, An ecological Christian anthropology: At home on earth?, Ashgate Publishing Limited, Aldershot.

Galston, W., 1991, Liberal purposes: Goods, virtues, and duties in the liberal state, Cambridge University Press, Cambridge.

Gewirth, A., 1984, 'Are there any absolute rights?', in J. Waldron (ed.), Theories of rights, Oxford readings in philosophy, pp. , University of Oxford Press, Oxford.

Putnam, R., 1993, Making democracy work: Civic traditions in modern Italy, Princeton University Press, Princeton.

Republic of South Africa, 1996, 'Bill of Rights', in Constitution of the Republic of South Africa,

South African Congress Alliance, 1955, Freedom Charter,

Van de Beek, A., 1996, Schepping, De wereld als voorspel voor de eeuwigheid, Callenbach, Baarn.

Vorster, J.M., 2004, Ethical perspectives on human rights, Potchefstroom Theological Publications, Potchefstroom. 